ISSN: $1412-4734$

E-ISSN: 2407-8646

Volume 18, Number 2, 2018

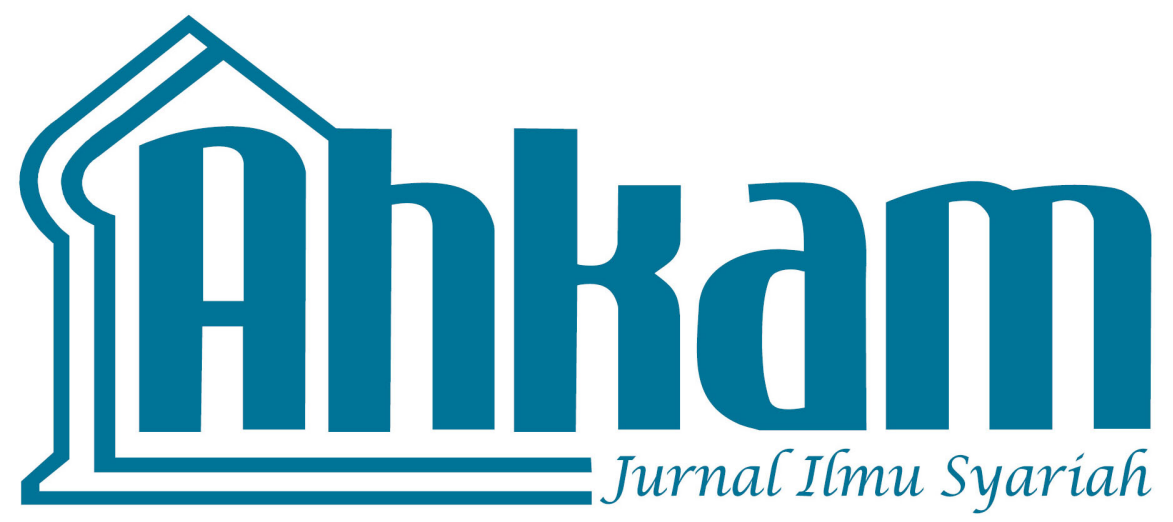

* Arifuddin Muda Harahap

Rules on Wage Standard to Improve Workers' Living Needs in the Perspective of Maqasid Al-Shari'ah

* M. IkHsan TanggoK

Circumcision Law in Christianity and Islam

* Abdul Rohman Zulfikar Alfaroug \& Nurhasanah The Positivisation of National Sharia Board Fatwa About Mudaraba into Financial Service Authority Regulation

* Muhamad Isna Wahyudi

Women Dealing With the Law in Religious Courts

* Arif Hidayatullah \& Anita Priantina

Toward Zakat Management Integration in Indonesia: Problems and Solution

* Muhammad Adil dan Muhamad Harun

Fiqh Melayu Nusantara in the Palembang Darussalam Sultanate Period

* Sugiri Permana

Implications of Hazairin and Munawir Sjadzali Thoughts in Establishment of Islamic Inheritance in Indonesia 


\section{Mhliam}

Volume 18, Number 2, 2018

\section{EDITOR-IN-CHIEF}

Khamami Zada

\section{EDITORS}

Fathudin

Maman R Hakim

Windy Triana

Nur Hidayah

Ahmad Bahtiar

\section{INTERNATIONAL EDITORIAL BOARD}

Tim Lindsey (University of Melbourne Australia)

Nadirsyah Hosen (Monash University Australia)

Ahmad Hidayat Buang (Universiti Malaya Malaysia)

Raihanah Azahari (University Malay Malaysia)

Mark Elwen Cammack (Southwestern University)

Razeen Sappideen (University of Western Sydney)

Carolyn Sappideen (University of Western Sydney)

Nik Ahmad Kamal bin Nik Mahmod (International Islamic Universiti Malaysia)

Ahmad Tholabi Kharlie (UIN Syarif Hidayatullah Jakarta)

Muhammad Atho Mudzhar (UIN Syarif Hidayatullah Jakarta)

Masykuri Abdillah (UIN Syarif Hidayatullah Jakarta)

Muhammad Amin Suma (UIN Syarif Hidayatullah Jakarta)

M. Arsykal Salim GP (UIN Syarif Hidayatullah Jakarta)

Asep Saepudin Jahar (UIN Syarif Hidayatullah Jakarta)

ASSISTANT TO THE EDITORS

Kamal F. Musa

Erwin Hikmatiar

ENGLISH LANGUAGE ADVISOR

Bradley Holland

Umi Kulsum

ARABIC LANGUAGE ADVISOR

Amany Burhanudin Lubis

AHKAM has been accredited based on the determination of Director General of Research Reinforcement and Development, Research, and Technology Ministry of Higher Education of Republic of Indonesia, No. 36/a/E/KPT/2016 (valid until 2021). 
AHKAM Jurnal Ilmu Syariah (ISSN: 1412-4734) is a periodical scientific journal published by Faculty of Sharia and Law of Syarif Hidayatullah State Islamic University Jakarta in collaboration with Indonesian Scientist and Sharia Scholar Association (HISSI). This journal specifically examines the science of sharia and obtains to present various results of current and eminence scientific research. The administrators receive articles as contributions Sharia and Islamic law disciplines from scientists, scholars, professionals, and researchers to be published and disseminated.

\section{EDITORIAL OFFICE:}

Fakultas Syariah dan Hukum UIN Syarif Hidayatullah Jakarta

Jl. Ir. H. Juanda 95 Ciputat, Jakarta 15412

Telp. (+62-21) 74711537, Faks. (+62-21) 7491821

Website: http://journal.uinjkt.ac.id/index.php/ahkam/index

E-mail: Jurnal.ahkam@uinjkt.ac.id 


\section{TABle of Contents}

251 Arifuddin Muda Harahap

Rules on Wage Standard to Improve Workers' Living Needs in the Perspective of Maqasid Al-Shari'ah

265 M. IkHSAN TANGgOK

Circumcision Law in Christianity and Islam

285 Abdul Rohman Zulfikar Alfaroug \& Nurhasanah The Positivisation of National Sharia Board Fatwa About Mudaraba into Financial Service Authority Regulation

305 Muhamad Isna Wahyudi

Women Dealing With the Law in Religious Courts

321 Arif Hidayatullah \& Anita Priantina

Toward Zakat Management Integration in Indonesia:

Problems and Solution

347 Muhammad Adil \& Muhamad Harun

Figh Melayu Nusantara in the Palembang Darussalam Sultanate Period 
375 Sugiri Permana

Implications of Hazairin and Munawir Sjadzali Thoughts in Establishment of Islamic Inheritance in Indonesia

395 RifQi QOWIyul ImAn

The Competence of Religious Court in Indonesia and

Syahadah Istifadhah (Testimonium De Auditu) in Case of Itsbat Waqf

417 Mustapa Khamal Rokan \& Kama Rusdiana Configuration of Costomary Law Related to Economy (Economic Adat Law Study in North Sumatera, Indonesia)

433 Yayan Sopyan \& Muhammad Shofwan Nidzami Nyabek Toloh Marriage Proposal Tradition in Madurese Culture: A Review of The Sociology of Islamic Law

453 Nuryani \& M. Musyafa

Linguistic Review on Marriage Age Regulation

463 Wetria Fauzi

Regulation of Sharia Insurance After the Enactment of Law No. 40 of 2014 Concerning Insurance 


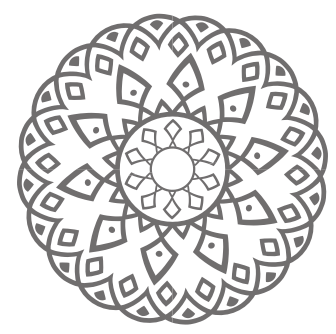

\title{
IMPliCATIONS OF HaZAirin AND Munawir Sjadzali Thoughts In Establishment of ISLAMIC INHERITANCE IN INDONESIA
}

\author{
Sugiri Permana
}

\begin{abstract}
Hukum waris merupakan salah satu kajian hukum Islam yang secara dinamis mengikuti perkembangan zaman. Sejarah menunjukkan ketika Masa Abu Bakr, dua tahun setelah wafat Nabi, hukum waris mengalami pembaharuan. Islam di Indonesia pun mengalami perkembangan pembaharuan hukum waris. Perkembangan ini tidak terlepas dari peran para ulama dan intelektual Indonesia. Pemikir terkemuka di bidang hukum waris di Indonesia ini adalah Hazairin dan Munawir Sjadzali. Keduanya terkenal karena pemikiran mereka menimbulkan kontroversi. Hazairin terkenal karena pemikirannya mengani kesetaraan antara cucu laki-laki dan perempuan. Sjadzali terkenal karena pemikirannya mengenai kesetaraan antara anak lakilaki dan perempuan. Pemikiran Hazairin cenderung masih dekat dengan nash Qur'an. Sedangkan pemikiran Munawir cenderung menyimpang dari harfiyah nash. Dalam perkembangannya, pemikiran Hazairin diadopsi dalam hukum waris di Indonesia. Kompilasi Hukum Islam telah mengakui keberadaan ahli waris pengganti yang salah satunya berasal dari pemikiran Hazairin yang memposisikan cucu perempuan setara dengan cucu laki-laki.
\end{abstract}

Kata kunci: hukum waris, Hazairin, Munawir Sjadzali 
Abstract: Inheritance law is one of Islamic law that always dinamically (*dynamically) follow the time. The history showed when abu bakr period, two years after the death of prophet, has renewed inheritance law. Indonesias (*Indonesia) became an important part of inheritace (Inheritance) law. This development isnt regardless from the thinker and scholar in Indonesia. Among scholar who have a great influence on inheritance law in Indonesia are Hazairin and Munawir Sjadzali. both of figures are famous for their controversy. Hazairin famous for the thought the equality of between grandchildren male and female. while sjadzali famous her thought the equality between man and women. Hazairin tend to think that is still near to the nash alquran, while munawir to deviates from nash provisions. In its development, the development of hazarin was adopted by inherentance law in Indonesia. the compilation of islam law has decided the existence of substitute heird ( ${ }^{*}$ Heard) in which one of them comes from the thought on Hazarin who positioned equally between granddaughter and grandson.

Keywords: Islamic Inheritance, Hazairin, Munawir Sjadzali

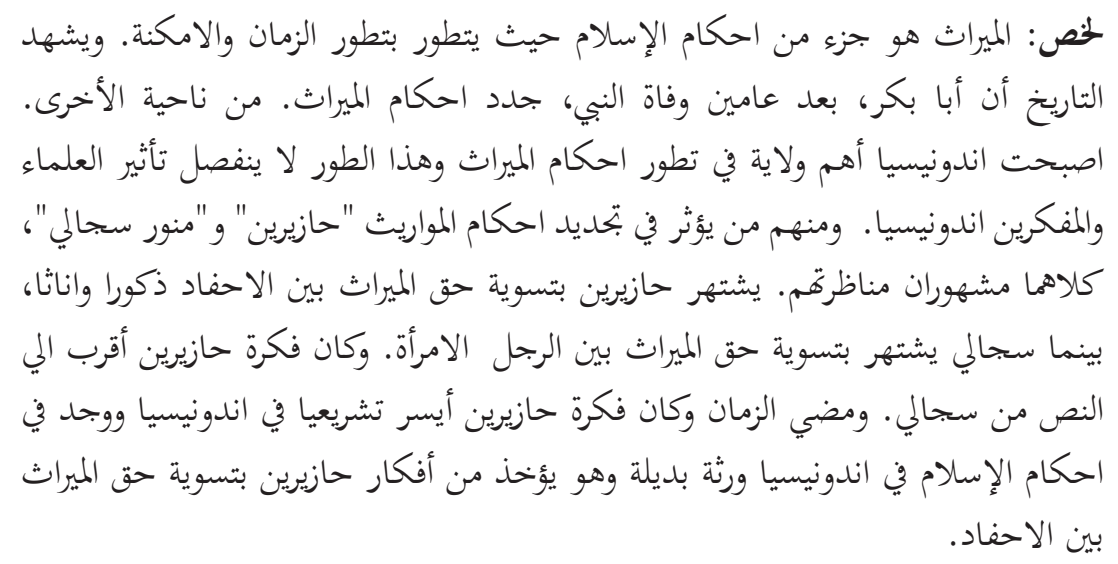

$$
\text { الكلمات المفتاحية: الميراث هو جزء من احكام الإسلام، حازيرين، منور سجالي }
$$




\section{Introduction}

Indonesian legal history is a confluence of three dinstinct systems of law among customary law, Islamic law and civil law. Not only legal history, but the national legal development is affected by these three systems. Such as the case of Islamic inheritance applied in Indonesia, which is only applied to Moslems and based on Islamic jurisprudence, meanwhile influenced by customary (adat) and civil law system.

Customary law (adat) in Indonesia as an ancient law that has been existed in Indonesia for long-time. This law was born and growth with the growth of human culture itself. Adat law society is based on genealogical or territorial system. Geneological system is divided into three types of patrilineal system (fatherhood), matrilineal (motherhood) and bilateral system (Hadikusuma, 2000:23). Kind of system showed the priority of right and obligation in its society. In a patrilineal society like in Batak, it prefers male lineage than the female lineage in rights and obligations. This is contrary to the matrilineal system in Minangkabau which prefers the descendants of women. In Javaland Bilateral system describes no priority for men or women lineage in law and social system even so given no same right and obligation. For example in some Javanese proverb's- that was affected by bilateral system—, sepikul segendongan, that explains the burden life of men more than women, and the right of men more than women.

Islamic law was born in Indonesia coincided with the introduction of Islam to indigenous people of Indonesia. A variety of historians indicates the existence of significant differences regarding the coming of Islam to Indonesia. Islamic law clearly shows the difference with customary law, but Islamic law becomes part of the daily life of Indonesian society, then the Islamic law should be a big part of customary law. According to Soepomo (1981:42) that customary law in Indonesia is largely a legal habit and a small part of Islamic law. The particular importance of inheritance in Islamic laws is obvious from the verses of Al-Quran and hadith of Nabi (peace be upon him). One of principle of Islamic inheritance, that male and female are equal degree and class to take inheritance the estate and the share of male is twice that of female as described in Al-Quran surah al-Nisa verse 12, Allah has assigned you (the heritage of) for your children, that of a son equal to two daughters. 
Regarding to Islamic sunni tradition, the heirs were classified to three groups. First, the sharers Ashhab al-furudl (spouses, parents, children, brother or sister) that declared specific portion in Al-Quran surah al-Nisa verse 11-12, 176. Second, the residuaries 'Ashabah, They are men closest to the deceased. The rights of the 'ashaba were recognized by the Prophet Muhammad SAW. Abdullah ibn Abbas ra. reported that the Prophet Muhammad SAW said, Give the Faraid (the shares of the inheritance that are prescribed in the Al-Quran) to those who are entitled to receive it. Then whatever remains, should be given to the closest male relative of the deceased (Sahih al-Bukhari). Third, dzawi alarham they are distance kindred, relate to a deceased from his female descendants (daughter's children, son's daughter's children) or other female relatives. The latest group have no right of inheritance when the two groups before alive (Nawawi Juz V: 10)

Another system of law has a big influential against the formation of laws in Indonesia is the civil law which was introduced by the Netherlands. The law basically comes from a variety of civil code de Francis (1804) which was reenacted in 1807 with the name of the civil code (Wirjono Prodjodikoro, 1983:9). In the year 1811 French colonized Netherlands and all of the civil code applied in the Netherlands. The Dutch colonized Indonesia since year 1596 and graduatally, the Netherland legal system applied into Indonesia. On the basis of the principle of concordance, Netherlands enacted a civil code (which is partly sourced from civil code) in Indonesia since January 1, 1848 upon established in 1847 the number 23. The principle of concordance is based on the IS (Indische Staatsregeling) of article 2, that stated the Europeas must be treated by the law as affected in the Netherlands in the field of civil law and commercial law (Ansori Ahmad, 1986:26-27).

Civil law showed a different position from the adat law and Islamic law in acquisition of inheritance. When in the adat law, there are the differences right every heir of estate depend on custom background, and Islamic legal inheritance described the difference tends to sexes, Kitab Undang-Undang Hukum Pidana/KUHP (civil code) guaranted women equal inheritance right with men, surviving spouses have a same right of the estate of their deceased, father (male) with mother (female) have equal right in the absence of the children. Another difference among KUHP with adat law and Islamic inheritance, that 
in KUHP, When child or spouse (husband/wife) who was still alive then the parents have no inheritance right. This is in contrast to Islamic inheritance law that gives rights to parents even though there is a child and the heirs of surviving spouses.

On the development of three legal systems above, then one another mutually influences. National legal system takes the values contained of adat law, which is also not apart from other legal systems. For example, in the law of the land, article 5 of the Act number 5 Year 1960 about the basic rules trees of agrarian states firmly that the agrarian laws that apply on Earth, water and space is adat law. And the other hand, the judge as law of power judiciary has an obligation to dig, follow and understand the legal valuest that live in the community. The judge can make a right decision that proper with the justice in the society, as defined in article 5 paragraph (1) of Act No. 48 of the year 2009 about the Powers of the Judiciary.

Referred to Indonesian legal development, then an inevitability if Islamic inheritance law in Indonesia occurred the convergence of three systems of law above, it can even happen the existence of other legal influences. Some scholars of Islamic law in Indonesia have tried to reconditional Islamic law with the model of Indonesian Islamic law. Hasbi Ash-Shiddieqy since the year 1940 had issued the nation of Islamic jurisprudence, Hazairin (d. 1975) who reconstruct Islamic law in view of the proximity of Indonesia society (Hazairin, 1974:18). In addition there is other Islamic renewal Munawir Sjadzali, (d. 2004) with the implementation of Islamic law.

The thought of the two latter intellectual has a special attention to development of Islamic inheritance in Indonesia. Hazairin was a prominent figure in Islamic law in Indonesia especially in Islamic inheritance. Hazairin and Sjadzali are two Islamic figures who have different academic backgrounds. In culture, both have the same background, educated by Islam traditionally. However, the formation of both intellect, Hazairin shaped by customary law background, meanwhile Sjadzali acquired Islamic education in tiered and symmetric starting from childhood to earn a Master's degree of Art is inseparable from Islamic studies. As well as his career, Minister of Religion during the two periods had been put in a position of influence against a map between the Islamic law in Indonesia. 
This paper will present, how big influence of two national figures and establishment of Islamic inheritance against Hazairin and Sjadzali in Indonesia? The study of the literature will dominate against the presentation of the history of thought both figures. In some cases in Islamic judicature was presented. This paper will be presented by normative basis, where the data obtained from the various ruling heirs either from the High court jurisprudence or from Islamic judicatur decissions.

\section{Hazairin and Bilateral Inheritance System}

Hazairin is a jurist with his full name Prof. Dr. Hazairin Alamsyah Harahap, SH. born in Bukit Tinggi on November 28, 1906 and died on December 11, 1975. Academic background is customary law (adat law), but later recognized also as an expert in Islamic law. This can be seen at the inaugural address as Professor of Islamic and customary law at the Law Faculty of the University of Indonesia in 1952. Formal education is education law schools Netherlands RHS (Rechtkundige Hoogeschool/ high school of law), while an understanding of Islam many retrieved from his grandfather Zacharias Bahar originating from Bengkulu, while his mother was a descendant of the Minangkabau. The different culture of his father and mother, make attention to Hazairin to deepen their customary law, so his dissertation about customary law entitled de Redjang, regarding Redjang customs in Bengkulu (Anshari, 2006:77).

Hazairin was educated by Netherlands legal system, but Hazairin's opinion is disproving the theory expressed by the Netherland experts. Hazairin refused the receptie theory proposed by Cristian Snouck Hurgronje. It considers this theory as a theory of Satan, because contrary to the Al-Quran and the Hadith and also creates a legal paradigm implicated to Indonesia politically. The type of receptie theory was a refressive law that impact to legal paradigm in colonial lands. In respect of receptie theory thus wos born the rules Section 134 subsection (2) IS a 1925 reduced several absolute competencies of Islamic judicature.

Hazairin thoughts about Islamic inheritance appeared in 1957 when presenting the theory of bilateral inheritance. The problems in the Hazairin research was the existence of Islamic inheritance sunni jurisprudence tends 
to be influenced by the patrilineal system. There is a difference of the position on the heir to the lineage, as granddaughter of daughter has no right with the granddaughter of son or even with the grandson of son.

Bilateral inheritance that popularized by Hazairin is obtained by way of paying attention to the Islamic inheritance through adat law and social anthropology. In accordance with background of Hazairin knowledge, Hazairin tried to see the phenomenon of social systems of adat law as a basis for analyzing the legal heir of Islam. In studies of the matrilineal and patrilineal system consequence against interclan marriage is not allowed. Unlike the bilateral system, there is no type of inter-clan marriage ban as contained in both systems before. In the matrilineal system, prohibited marriage between a descendant of the brother-mother. Like Minangkabau communities who avoid marriage between fellow grandson of daughters, wherever possible a man married to a female child mamaknya (mother's brother). So with a patrilineal system, Batak on abstinence for married women who are in the same kinship system (called marga). Both the prohibition of marriage form exogamy (marriage between people of different social groups or categories) and endogamy (marriage between people of the same social group or category) was not found in the bilateral system.

Hazairin reviewed surah al-Nisa verse 23-24, And marry not women whom your fathers married, except what is past: It was shameful and odious, an abominable custom indeed. Prohibited to you (For marriage) are: Your mothers, daughters, sisters; father's sisters, Mother's sisters; brother's daughters, sister's daughters; foster-mothers (Who gave you suck), fostersisters; your wives' mothers; your step-daughters under your guardianship, born of your wives to whom ye have gone in,- no prohibition if ye have not gone in; (Those who have been) wives of your sons proceeding from your loins; and two sisters in wedlock at one and the same time, except for what is past; for Allah is Oft-forgiving, Most Merciful.

Hazairin argued that the Al-Quran tends to use bilateral kinship system, where there is no prohibition of marriage between persons representing the nephew, regardless of the line of girls or boys. In the science of anthropology, known wedding between nephew namely cross cousin (a marriage between two grandchildren who their mothers or fathers are brothers), parallel cousin (a marriage between two grandchildren whose mother or father are brothers). The ban on top 
of both types of marriage requires the existence of a wedding exogamy, wedding outside of the clan.

In the history of the prophetic, there are practice marriages cross cousin and parallel cousin, the daughter of the Prophet, his name Zainab binti Muhammad peace be upon him was the eldest daughter of Islamic prophet Muhammad by his first wife, Zainab married her maternal cousin Abu al-Ash ibn al-Rabi' who was Khadijah sister's named Hallah bint khuwaylid. The daughter of another Prophet named Ruqoyah and Umm Kultsum was married son of Abu Lahab, 'Utbah and Utaibah which is a descendant of the uncle of the prophet (Sugiri Permana, 2015:5).

Matrilineal and patrilineal system in Indonesian society not only implies the marriage system, but also influences to the law of inheritance. In the matrilineal system, women's lineage more prioritized than the male lineage in the division of property remains. So with a patrilineal people, has broader implications, provide more opportunities to the sons of men in obtaining inheritance (Soerjono Soekamto, 2010:218). Arab society, viewed by Hazairin is a society with the pattern of a patrilineal people, because the system that prioritizes the inheritance lineage of men or the male agnate relatives. There were rules of priority, which determined of the surviving male agnates and group of heirs called Quranic heirs or sharers (ashab al-furudl) were entitled to inherit and exclude distance kindred/relatives (dzawu al-arham) (Anwar Harjono, 1977:62).

Regarding to Hazairin thought of bilateral system of Islamic society in the Al-Quran, then the system should also be applied in Islamic inheritance. Based on understanding, than between the descendants of men and women should have equal opportunities to inherit his grandfather/grandmother estates. Therefore perceived wrongly if granddaughters of daugther considered to have no inheritance, while at the same time a granddaughter of son has inheritance.

The Hazairin concept is supported by mawali that results interpretation against the Qur'an Al-Nisa [4] verse (33) For each property of the abandoned possessions of mother father and close relatives, we made his successors. And (if any) people who you swear allegiance to them, then give it to them his portion. In truth God saw everything. 
According to Hazairin theory (1974:12), this verse requires for everyone there mawali as his heir. As an example of someone who has a child who died, then when that person died, replaced by the son of heir (his grandson). In various books of tafsir Al-Quran, there isn't exegesis prescribe the mawali beneficiary with a replacement. Al-Thabari interpreted mawali with ashabah (residuaries) and the beneficiary. This opinion also followed by al-Razi and al-Baghawi (Sugiri Permana, 2014: 288). According to Anshori (2006:179), Hazairin classified to filusuf connecting intellectual puritanism faith, he classified the hamly exegetes that referred his conviction on a question of interpretation.

In more detail, there are general bilateral inheritances expressed by Hazairin:

The heirs male and female are equal degree and class to take inheritance the estates. Second, A line of female relatives is same position with line male relatives. Third, the concept of Mawali in the Qur'an according to the Hazairin defined as the heirs of a replacement. Impediments to inheritance only in virtue of the primer group to the descendent. In accordance with surat al-Nisa verse 7 , the offspring of men and women have equal rights to acquire inheritance. Kalalah are heirs who did not have descendants, so that if there is a daughter or child, then the brother by itself would be hindered. Equality of Descendants, men and women will implies grouping heirs. In view of the Hazairin, there is no relatives dzawil arham group, because this group is essentially a line of female or male offspring who are hindered by men. This provision also applies to the line sideways or upwards (ancestors). The final conclusion of bilateral heir is the concept of mawali who later interpreted as heirs of the replacement substitution of ahli waris or bij plats verpulling in civil law system $(K U H P)$.

\section{Munawir Sjadzali and Equal Right Inheritance}

Munawir Sjadzali was born in Klaten, Central Java Anom Reef, 7 November 1925. Her teenage education years spent at Manbaul Ulum boarding schools until completed his education at the high school of the Manbaul Ulum Solo in 1943. Sjadzali completing formal education at Georgetown University United States the year 1959 Political philosophy with the thesis of Indonesia's Moslem Parties and Their Political Concepts. Education background has positioned Sjadzali as important position, some Embassy of Indonesia until he became 
Minister of religious affairs in Suharto's era at two periods 1983-1988 and 1988-1993 (Munawir Sjadzali, 1994:42).

After resign as Minister of religious affairs, he is appointed to be a member of the DPA (Grand Consideration Council) and became the Chairman of the Commission of Human Rights. On 22 February 1994 Sjadzali assumed the title of Doctor Honoris Causa (honorary doctor) at IAIN (now UIN) Syarif Hidayatullah Jakarta. This College will place his carrier until he died at the age of 78 years, exactly on 23 July 2004.

Munawir Sjadzali has a controversial thought about the Islamic inheritance. Generally in Islamic jurisprudence, the share of property inherited by a female heir is half of the property given to a male. Sjadzali (1988:2) proposed that women equal to men in inheritance as defined by civil law (KUHP). He point out the legal reasons, because a female gets half of what a male gets in Islamic inheritance has been abandoned by the Moslems of Indonesia either directly or not. Some research also appears to support Sjadzali thought, such research Otje Salman (Professor from UNPAD) in 1992 with the title of the dissertation "The Implementation of the Law of Inheritance in the Cirebon Area seen from the Legal Heir of the Islamic Inheritance Laws and Customs".

Sjadzali has presumption, if a devout moslem who is sticking with the teachings of Islam, the Al-Quran and hadith, while it does carry out the legal heir in accordance with what is interpreted, there are concerns that Islamic teachings are not accordance with the times. Therefore it would be more fairness to take action that is more honest than quibble with looking for evidence that can be found on the hilah.

Sjadzali (1997:8) also provides illustrations of the habit of the elderly in the community more seeks her son, so with more fees earned by the boys, it seems will reflect an inequity when the son gets a share equipalent of two females. Sjadzali paid attention to the practice of hilah done by many scholars by dividing the estate to his daughter and son as Hibah. Gift intervivos hibah is a transfer of property made during a person's lifetime. Hibah makes more assurance to give equal right for male and female offspring without discrimination based on gender. $\mathrm{KH}$ Ali Darokah (Islamic scholar Surakarta) becomes references, because the Kyai became one of the scholars who approved the idea of 
granting equal rights between son and daughter on the grounds in the region of Surakarta's wife became the backbone of the family company starting from the preparation of the white cloth of batik production to marketing.

The basic thought of Sjadzali is contrasts with the concept of Hazairin theory. Hazairin Thought of bilateral inheritance based on Al-Quran surah al-Nisa verse 7, 23-24 and 33. And the other hand, The equality inheritance on Sjadzali thought tended to sound across from nash Quran surat al-Nisa verse 11 which sets out that the rights of men was twice that of women's rights.

In terms of Islamic inheritance, division equal between the inheritance of men and women just happen to mother's brother. Either male or female, the mother's brother has equal rights of inheritance. The term are different from father brother's and father mother brother's that the right of estate as well as son and daughter. As described surat al-Nisa verse 11, If the man or woman whose inheritance is in question, has left neither ascendants nor descendants, but has left a brother or a sister (mother's), each one of the two gets a sixth; but if more than two, they share in a third; after payment of legacies and debts; so that no loss is caused (to any one). Thus is it ordained by Allah and Allah is All-knowing, Most Forbearing. Most exegates explain the brother and sister in this verse is the brother and sister mother's. This verse stated that the mother's brother, male or female have equal rights of inheritance (Nawawi, 2002:16).

Equality of inheritance can be found on the contemporary jurisprudence of several Islamic countries, Turkey is the country which the majority of Islam do inheritance equality between men and women. In the Turkish Civil Code of 1926 which has undergone some changes, assign equal rights between men and women. The application of the law of inheritance in Somalia as well as in Turkey. In The Family Code of Somalia, Somalia established equal rights between men and women in obtaining inheritance. According to Taher Mahmod (1972:2) has classified Turkey and Somalia as Islamic countries whom leaved some Islamic jurisprudences especially in family law and succeeded with civil law derived from Europe. 


\section{Consideration to Hazairin and Sjadzali Thought in Islamic Inheritance in Indonesia}

The Dynamics of the Islamic inheritance in Indonesia can be found in the compilation of the Islamic law (KHI) and the jurisprudence of the Supreme Court as well as some first-level judicial ruling. Compilation of Islamic law imposed based on presidential instruction No. 1 of the year 1991, is a representation of Islamic jurisprudence that has been adapted to Indonesian law. KHI consists of three books, each book concerned with a different subject (Book I is about marriage, Book II is about Inheritance and book III is about Waqf), KHI is a law materially born after promulgation of Act No. 7 of 1989 Year religious courts. The true birth of KHI no relation of causality with the promulgation of the act of religious courts, because KHI already designed since a few years earlier. They are the two national figures, first, Bustanul Arifin (Honorable Justice) who presented the Supreme Court and second, Munawir Sjadzali (Minister of Religion) which culminated in the birth of the Joint Decree between the Supreme Court and the Minister of religious affairs number 07/KMA/1985. The joint decree as the legal basis of preparation Islamic jurisprudence based on social condition of Indonesia (KHI).

As time passes, three family law discussion in $\mathrm{KHI}$ has experienced a variety of developments, even discussion of endowments is already considered not applicable because it was born to Act No. 41 of 2004 Year about Waqf which then its implementation is governed by government regulation Number 42 Year 2006 about the rules of the implementation of Act No. 41 of the year 2004. Based on the theory of law lex superior derogate legi inferior (higher law omitted the lower law degree) and the theory of lex posteriori derogate legi priori (the law which was born first defeated by law which was born later), then the provisions contained in Book III is no valid.

Book $\mathrm{I}$ is about marriage being a complement of law number 1 Year 1974 and Government Regulation No. 9 of the year 1975. In addition to both the regulation have also been born some rules of practice such as the regulation of the Minister of religion 30 year 2005 Number... of guardians the judge and Minister of religious affairs Regulation number 11 Year 2007 about Registration of marriage. Some of the rules contained in the law of marriage also "corrected" by the 
Constitutional Court. The ruling of the Constitutional Court No. 46/ PUU-VIII/2010 ladder 17 February 2012 insists that children born outside marriage has civil relations with her mother and her mother's family as well as with the men as her father can be proven based on Science and technology and/or other proof according to law had blood relatives, including her father's relationship with the family of the civil code". The verdict replaced the content of article 43 paragraph (1) that says children born outside marriage has only civil relationship with her mother and her mother's family. The same content is also contained in section $100 \mathrm{KHI}$. Covenant marriage also became part of the "corrected" by the ruling of the Constitutional Court the number 69/PUU-XIII/2015. Based on the verdict, then the provisions of the Covenant marriage can only be done before or at the time the marriage took place as described by article 29 (1.4) law number 1 Year 1974 became invalid, so that spouses can do the agreement either before, at the time he did the marriage or during the marriage takes place.

KHI Book II discusses inheritance also has undergone significant developments. There are 43 article about inheritance law including wills and bequests, starting from Article 171 to article 214. The principles of classical Islamic inheritance still retained, as in article 176 stated that the daughter when she alone get a half part, when two or more daughters, they get two-thirds part, and when the daughter get together with the son, then part of the son are two against the one with the daughter.

A comparison half share women of men also applied to mother and father as described in article 178 paragraph (2) KHI. Mother gets one third of the estate after being taken by a widow or widower when she is with a father. And female get half share of male also applied to brothers as described in Article 182, When a person dies without leaving a child and a father, while he has one father mother brother's or father brother's, then He gets half of the parts. If the sister is with a father mother brother's or two or more father mother brother's, then they get two-thirds together. If the sister is with a father mother brother's or father brother's, then the brother's part is two to one with the sister.

This fact describe that the concept of ijtihad, which is carried by the influential Sjadzali didn't consider against the principle of the law of inheritance applicable in Indonesia. Sjadzali-then became Minister of Religion—not trying to impose his tought, he separate his 
how the results that have the potential for disagreements with other scholars. If Sjadzali tried to confuse between his position and ijtihad, "maybe" can only enforce it because the process itself KHI occured when Sjadzali became Minister of religion. Such facts also occurs when Sjadzali "comment" about illegitimately married between the bride in Jakarta with the bridegroom who was in Amerika. The case of marriage with a Covenant of marriage by phone is the first time has happened. Sjadzali which when it became Minister of Religious Affairs stated that the marriage is invalid. The marriage was then enacted by the religious Court in South Jakarta with the matter Number 1751/P/1989. At the time of Sjadzali became a lecturer at UIN Jakarta, then he was asked about the case of a wedding like that and he said that the marriage was valid.

\section{Comparing Hazairin and Sjadzali Thought on Islamic Inheritance in Indonesia}

The concept of mawali Hazairin can be seen on KHI article $185 \mathrm{KHI}$ which confirms that (1) the heirs who died earlier than praepositus then its position can be replaced by his son/daughter, except those mentioned in Article 173 (2) the beneficiary shall not exceed replacement of the part of the beneficiary which is the equal of being replaced. Replacement on KHI Article 185 didn't mention the existence of the concept of mawali-as does the concept of Hazairin thought, but tend to choose a representation beneficiary, i.e. the successor succeeds heirs who died earlier compared to the heir.

Application of representation heirs in KHI effected by the protection against descendants of the heirs have no right caused heirs died ahead of the heir. Classical jurisprudence asserted that the grandchildren or granddaughter of daughter have no right of property deceased when there are son or daughter. The position of grandchildren or granddaughter of daughter will be excluded by son or daughter. The granddaughter of son position was better than grandchildren or granddaughter of daughter, because he has right one of six (1/6) with daughter but he same position with grandchildren or granddaughter of daughter if there are daughters or son.

Doctrine of representation was well known principle recognized by the Roman, English and Hindu law of inheritance. Islamic inheritance 
didn't recognize the doctrine of representation. In earlier Islamic legal development, the doctrine representation arouse with varieties model. The concept of representation is intended to protect the granddaughter of daughters, or granddaughters of son when there are excluded by existance of child (male or female). Meanwhile, the grandson of son, according to the classical Islamic jurisprudence are treated as son as position, so that even his father died before from his grandfather (the descendant), grandson remains has right to inherite the estates.

The protection was applied in KHI against grandchildren (who left dead by the beneficiary before the heiress died) that are not for inheritance is not the first time, the concept of representation has happened in the development of Islamic inheritance law. Egypt as a trigger country promoted to protect the heir grandchildren using the concept of will obligation. Protection of the grandchildren by family law of Egypt different from KHI. Islamic Jurisprudence (KHI) in Indonesia enacted a replacement heir in general condition, both grandchildren of son or daughter who are entitled to take inheritance or not eligible may be positioned as a replacement heir.

Egypt is strictly enforcing will obligation, meaning that not all grandchildren obtaining will obligation but with some specific criteria. The first grandchild is not the heir position, second grandson hasn't gotten earlier inheritance and third, grandchildren didn't get will before. These provisions may be seen in section 77-78 of the Act Number 71 Years 1946 Egypt about a will.

Substantially, when compared with the concept of will obligate in Egypt, the heir replacement in the KHI is more used from civil law system. In KUHP, known the existence of the direct heirs uit eigen hoofde and heirs who replaced the position of his parents later called replacement heir or bij plaats vervulling. Provision of replacement heirs can be found in section $841 \mathrm{KUHP}$ replacement is a right given to one to replace an heir who had died prior to his succession was acting as a surrogate in degrees and in the rights of the person it replaces. The section 841 stated that KUHP as promulgated since May, 11848 has recognized the replacement heir (Ismuha, 1978:73). Soepomo explained that KUHP gave more detail about heir replacement. First, the replacement in the bottom line with no limits, like a grandson who replaced his son, a great grandchild who changed the position of grandchild and child. Second, 
replacement in the line to the side, when brother, both siblings and half-siblings if died earlier replaced by children. Third, the replacement in the side line that comes forth as the heirs is the family members who further the degree of relationship of a brother.

Al-Jazair is one country that heir replacement used the term with the name al-tanziil. Strong allegations, the replacement of the beneficiary at the al-Jazair is influenced by the French legal system, which colonized the country more than 100 years. Al-Jazair gained independence from France in 1962. Algerian family law, known as the Family Code of 1984, enacted June 91984 Algeria. Doctrine replacement propose to protect against a grandson who was left to die by his parents. In its application, although AlJazair uses the nomenclature "replecement beneficiary", but still applying the provisions contained in the wills obligation in Egypt.

Conceptually, the heirs raised by replacement from Hazairin thought comes from the meaning of the mawali founded in surat alNisa verse 33. When he lived between the years 1906-1975, it is the time whene KUHP has taught at several universities in Indonesia. However, there is no one stated that Hazairin thought adopts bij plat vervulling as described in KUHP paragraph 841.

The concept of the replacement is the application of equity position of heirs male and female. The replacement of heirs is also application giving priority to heredity as long as there are groups more mainstream then other groups. For the first group (children, parents and spouses) then other groups namely the brother will not get the rights. By implication, the daughter will exclude brother as well as son.

In the corpus of Islamic thought, the equivalence of the position of men and women there are in the Shiah, the Shiah is not a respecter of gender for the heirs who will spend the treasures, but rather put forward the level of closeness with the heir. As long as there is still a child of daughter, then other heirs (brother and sister) have no right inheritance (Vikor, 2005:238).

Shia law divides legal heirs into three basic classes. These classes thereafter determine distribution of an estate among legal heirs and how to give preference to one legal heir over another. Appropriate appreciation of these classes helps one to understand Shia law of 
inheritance as details of the system in one manner or another are linked to it. These classes are the following:

The first class, parents and children (male and female). The children also include their descendants how low so ever irrespective of the fact whether they are descendants of male or female children. Second class 2: Grandparents (true or false) how high so ever, and Brothers and sisters (full, consanguine, and uterine) and their descendants how low so ever irrespective of their gender. Third class, paternal uncles and aunts, Maternal uncles and aunts, and Their children how low so ever irrespective of their gender. The heirs are divided into the above classes, there are two basic rules which need to be understood. All the Classes will get inheritance right with spouses's inheritance. The effect of living first class, the second class have no right of inheritance and the absence of second class, than the third class have right of inheritance (Cheema, 2012:70-71).

According to Nurlaelawati $(2010: 152)$ the position of girls who exclude the brother is the legal heir deviation of Islamic jurisprudence (sunni). These lapses, however, are apparently supported by some ruling the Supreme Court verdict. Some Court verdict showed that daughter excluded the brother position in right of inheritance: The Supreme Court verdict 1. Number 86K/AG/1994 dated July 20, 1995 2. The Supreme Court verdict Number 184 K/AG/1995 dated September 30, 1996 3. The ruling of the Supreme Court Number 327K/AG/1997 dated February 26, 1998.

In the development of contemporary jurisprudence in some muslim countries, the position of brother or sisters hindered by daughter found in the State of Tunisia. Tunisia also gave radd for ashhab al-furud include husband or wife and the granting of equal rights to women and their descendants, and exclude inheritance right of brother (Tahir Mahmood, 1987:152). Along with Turkey, Tunisia has taken the most secularized approach to women's rights in majority-Muslim countries, and Tunisia afforded women full and equal rights and remains one of the most progressive family laws in the Arab world today (Charra, 2012:1-2).

Meanwhile from normative inheritance law in Indonesia asserted that a male heir will have double share of a female heir, the other hand, there are verdicts of religious court decide that daughter have equal 
right of son. The verdict of Religious court of Medan Number Nomor 92/Pdt.G/2009/PA. Mdn devided the deceased property among nine heirs, 5 sons and 4 daughter are equal, each heir get 1/9 of deceased property. The verdict explained that one of heir (son) has died before the deceased, the son left three daughters and one son. The judge also decided, that the three granddaughter of son and one grandson of son get equal right from $1 / 9$ of deceased property. While the verdict didn't consider the equal right inheritance form Sjadzali thought, the verdict verified that equal right have possible to applied in certain case.

Be sides the verdicts of Religious court, there are decries of religious court (proceed without dispute) decide equal inheritance right between male and female heirs. The decries are following:

1. Decree of Religious Court of Cikarang Nomor: 01/P3HP/2007/ PA.Ckr tanggal 15 Mei 2007

2. Decree of Religious Court of Cikarang Nomor: 01/P3HP/2008/ PA.Ckr tanggal 15 Januari 2008

3. Decree of Religious Court of Cikarang Nomor: 2/P3HP/2008/ PA.Ckr tanggal 28 Januari 2008

4. Decree of Religious Court of Cikarang Nomor: 08/P3HP/2008/ PA.Ckr tanggal 5 Mei 2008

5. Decree of Religious Court of Cikarang Nomor: 11/P3HP/2008/ PA.Ckr tanggal 19 Juni 2008

The decries assert all of heirs have equal right of deceased property based on agreement. The judges decided the equal portion based on heirs agreement after the heirs knew each portion or without knowing portion.

\section{Conclusion}

Comparison between the concept bilateral inheritance of Hazairin thought and equality inheritance of Sjadzali thought in development of Islamic inheritance law in Indonesia as described before, showed that Hazairin thought is more affecting than Sjadzali. Heir replacement, brother excluded by a child (male or female) are facts that Hazairin tought had affected for Islamic inheritance in Indonesia. On the other hand, equal right of Sjadzali tought founded in some verdict/ Religious judicature declares that assert female equal to male. This paper is 
not stated expressly, that Islamic inheritance in Indonesia is affected by Hazairin thought directly, because of some historical review law apparently Hazairin thought also carried from the other system of law such as family law from other Islamic countries, civil law system and Shi'a family law.[]

\section{References}

Akhmad Muslih, "Legal Political Thought of Christian Snouck Hurgronje In Indonesia Legal System Development, South East Asia Journal of Contemporary Business, Economics and Law, Vol. 10 , Issue 4 (Aug.) ISSN 2289- 1560, 2016 http:// seajbel.com/wp-content/uploads/2016/09/K10_6.pdf

al-Nawawi, Rawdhat al-Thalibin Juz V, Beirut: Dar 'Alami al-Kutub, 2002.

Anshori, Abdul Ghofur. Filsafat Hukum, Sejarah, Aliran dan Pemaknaan. Jogjakarta: Gajah Mada Press, 2006.

Ansori Ahmad, Sejarah dan Kedudukan BW di Indonesia, Jakarta: Rajawali, 1986.

Aris Fadhillah Samsir, "Ethic and Legal Professions the Ethic of Judge in Indonesian Approach", www.academia.edu/4408920/2012

Goode J.William, Sosiologi Keluarga, Jakarta: Bumi Aksara, 2004.

Harjono, Anwar. "Hukum Kewarisan Bilateral Menurut Al-Qur'an Komentar Singkat Atas Teori Prof. Hazairin," dalam Sajuti Thalib, Pembaharuan Hukum Islam di Indonesia In Memoriam Prof. Mr. Dr. Hazairin. Jakarta: UIPress, 1977.

Hazairin, Tujuh Serangkai Tentang Hukum Jakarta: Tinta Emas,1974.

Hilman Hadikusuma, Hukum Kekerabatan Adat, Jakarta: Fajar Agung,2000.

Ismuha, Penggantian Tempat Dalam Hukum Waris Menurut KUHPerdata, Hukum Adat dan Hukum Islam, Jakarta: Bulan Bintang, 1978.

Knut S. Vikor, Between God an the Sultan A History of Islamic Law, New York, Oxford University Press, 2005.

M.Idris Ramulyo, Perbandingan Hukum Kewarisan Islam di Pengadilan Agama dan Kewarisan Menurut Undang-Undang Hukum Perdata (BW) di Pengadilan Negeri, Jakarta: Pedoman Ilmu Jaya, 1992.

Mounira M. Charra, Family Law Reforms In The Arab World: Tunisia And Morocco, New York, 2012.

Munawir Sjadzali, "Reaktualisasi Ajaran Islam." dalam Iqbal Abdurrauf Saimima, ed., Polemik Reaktualisasi Ajaran Islam, Jakarta: Pustaka Panjimas, 1988.

Munawir Sjadzali, Bunga Rampai Wawasan Islam Dewasa ini, Jakarta: UI Press, 1994.

Munawir Sjadzali, Ijtihad Kemanusiaan, Jakarta: Paramadina, 1997.

Nurlaelawati, Euis, Modernization, Tradition and Identity The Kompilasi Hukum Islam and Legal Practice in Indonesian Religious Courts. Amsterdam: Amsterdam University Press, 2010. 
Pragati Ghosh, General principles of inheritance under muslim law in India, www. shareyouressays.com/117457/13-

R. Soepomo, Bab-bab tentang Hukum Adat, Jakarta, Pradnya Paramita, 1981.

Raymond Scupin, Cultural Antrophologi a Global Perspektif, Person, USA, 2012.

Shahbaz Ahmad Cheema, "Shia and Sunni Laws of Inheritance: A Comparative Analysis", Shia and Sunni Laws of Inheritance: A Comparative Analysis, Pakistan Journal of Islamic Research Vol 10, 2012.

Soerjono Soekanto, Hukum Adat Indonesia, Jakarta: Rajagrafindo Persada, 2010 Subekti, Pokok-pokok Hukum Perdata (Jakarta: Intermasa, 2005), 100-101.

Sugiri Permana, "Kinship Terms dan Pemetaan Hukum Waris Islam Kajian atas Perbedaan Hak Waris Saudara Sekandung, Sebapak Dan Seibu” www.badilag. net

Sugiri Permana, Dasar Penetapan Kewarisan Pengadilan Agama, Studi Atas Penetapan - Penetapan Waris Pada Pengadilan Agama Bogor, Cianjur dan Cikarang Jawa Barat pada Tahun 2006-2010, Jakarta: Pustikom, 2014.

Tahir Mahmood, Personal Law in Islamic Countries History, Text And Comparative Analysis. New Delhi : Academy of Law and Religion, 1987.

Tahir Mahmood, Family Law Reform in The Muslim World, New Delhi: The Indian Law Institute, 1972.

Tim Penulis IAIN Syarif Hidayatullah, Ensiklopedi Islam Indonesia, Jakarta: Djambatan, 2002, Cet. Ke-2.

Wirjono Projodikoro, Azas-azas Hukum Perdata, Bandung: Sumur Bandung, 1983.

Zaenul Mahmudi, Wasiat: Solusi Alternatif Dari Pembagian Warisan Yang Tidak Adil? de Jure, Jurnal Syariah dan Hukum, Volume 5 Nomor 2, Desember 2013.

Zezen Zaenal Mutaqin, "Indonesian Customary Law and European Colonialism:A Comparative Analysis on Adat Law" http://www.thailawforum.com/articles/ Indonesian-Customary-Law-and-European-Colonialism.html

Sugiri Permana, Chief Judge of Religious Court of Martapura, South of Kalimantan 


\section{Mhliam}

AHKAM Jurnal Ilmu Syariah (ISSN: 1412-4734/E-ISSN: 2407-8646) is a periodical scientific journal published by Faculty of Sharia and Law of Syarif Hidayatullah State Islamic University Jakarta in collaboration with Indonesian Scientist and Sharia Scholar Association (HISSI). This journal specifically examines the science of sharia and obtains to present various results of current and eminence scientific research. The administrators receive articles as contributions Sharia and Islamic law disciplines from scientists, scholars, professionals, and researchers to be published and disseminated. The article will be situated in a selection mechanism, a review of proved reders, and a strict editing process. All articles published in this Journal are based on the views of the authors, but they do not represent the authors' journals or affiliated institutions.

AHKAM has been accredited based on the determination of Director General of Research Reinforcement and Development, Research, and Technology Ministry of Higher Education of Republic of Indonesia, No. 36/a/E/KPT/2016 (valid until 2021). 